\title{
Sense and simplicity: dilemma's en parallellen in de perioperatieve zorg
}

Citation for published version (APA):

Marcus, A. E. (2010). Sense and simplicity: dilemma's en parallellen in de perioperatieve zorg. Maastricht University. https://doi.org/10.26481/spe.20101119am

Document status and date:

Published: 19/11/2010

DOI:

10.26481/spe.20101119am

Document Version:

Publisher's PDF, also known as Version of record

\section{Please check the document version of this publication:}

- A submitted manuscript is the version of the article upon submission and before peer-review. There can be important differences between the submitted version and the official published version of record.

People interested in the research are advised to contact the author for the final version of the publication, or visit the DOI to the publisher's website.

- The final author version and the galley proof are versions of the publication after peer review.

- The final published version features the final layout of the paper including the volume, issue and page numbers.

Link to publication

\footnotetext{
General rights rights.

- You may freely distribute the URL identifying the publication in the public portal. please follow below link for the End User Agreement:

www.umlib.nl/taverne-license

Take down policy

If you believe that this document breaches copyright please contact us at:

repository@maastrichtuniversity.nl

providing details and we will investigate your claim.
}

Copyright and moral rights for the publications made accessible in the public portal are retained by the authors and/or other copyright owners and it is a condition of accessing publications that users recognise and abide by the legal requirements associated with these

- Users may download and print one copy of any publication from the public portal for the purpose of private study or research.

- You may not further distribute the material or use it for any profit-making activity or commercial gain

If the publication is distributed under the terms of Article $25 \mathrm{fa}$ of the Dutch Copyright Act, indicated by the "Taverne" license above, 


\section{Maastricht University}

\section{Prof. Dr. A.E. Marcus}

Faculty of Health, Medicine and Life Sciences

\section{'Sense and Simplicity':}

Dilemma's en parallellen in de perioperatieve zorg

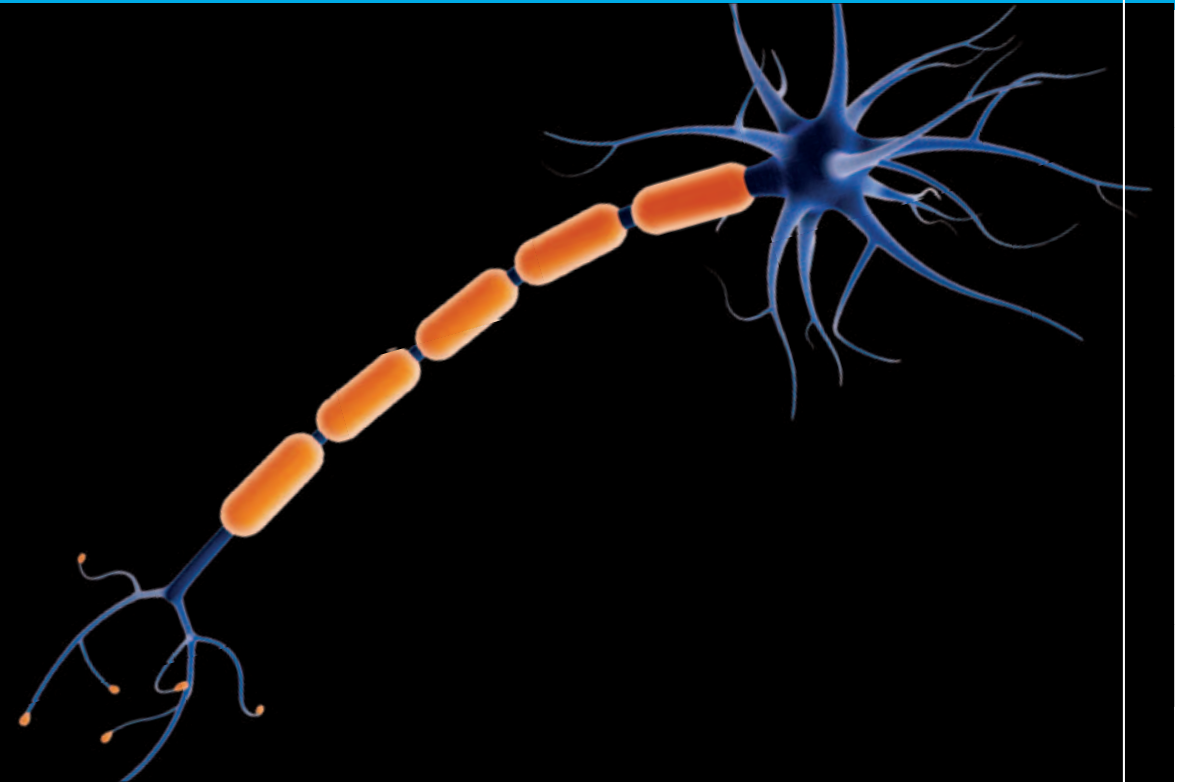


'Sense and Simplicity':

Dilemma's en Parallellen

in de perioperatieve zorg 


\section{Colofon}

Ontwerp en print: Océ Business Services, Maastricht

ISBN: 978-90-5681-350-5

NUR: 870

Alle rechten voorbehouden. Niets uit deze uitgave mag worden verveelvoudigd, opgeslagen in een geautomatiseerd gegevensbestand of openbaar gemaakt worden, zonder voorafgaande schriftelijke toestemming van de auteur of uitgever. 


\section{'Sense and Simplicity': \\ Dilemma's en Parallellen \\ in de perioperatieve zorg}

Inaugurele rede

Maastricht, 19 november 2010

Door Prof. Dr. A.E. Marcus 
Dames en Heren, Mijnheer de rector magnificus, geacht College van Bestuur, geachte decaan, geachte Raad van Bestuur, beste collega's, familie, vrienden en overige toehoorders. Vandaag zal ik deze inaugurele rede voor $u$ allen uitspreken.

\section{Inleiding}

De term dilemma duidt gewoonlijk een keuze aan uit twee of meer alternatieven, die even aantrekkelijk dan wel onaantrekkelijk zijn. De keuze kan daarom niet alleen op logische basis gemaakt worden. De weg uit een dilemma is vaak een zeer persoonlijke. Euripides schreef bijvoorbeeld in de Griekse tragedie "Iphigeneia in Aulis" dat Koning Agamemnon voor de keuze gesteld wordt: Hij kan zijn dochter Iphignea offeren en de Trojaanse oorlog winnen, of haar sparen en de oorlog verliezen: de keuze dus tussen zijn land en zijn dochter. Een onmogelijke keuze?

Een aantal dilemma's waar wij mee geconfronteerd worden wil ik graag vandaag met $u$ bespreken. Waarschijnlijk niet van die onmogelijke als de voorgaande, maar toch dilemma's waar wij als anesthesist maandelijks, wekelijks maar soms ook dagelijks mee geconfronteerd worden. Om dit te illustreren is deze rede een drieluik. In het eerste deel zal ik een dilemma in de operatiekamer bespreken. In het tweede deel een dilemma dat ik tegenkom in de opleiding tot anesthesist, en in het derde deel een dilemma bij het wetenschappelijk onderzoek. Na elk stukje ga ik erop in of er parallellen te vinden zijn in de economie, de geschiedenis of andere vakgebieden. Aan het eind van de rede zal ik proberen een rode draad voor u samen te vatten en een oplossing aan te dragen. 


\section{Eerste deel van het drieluik: De anesthesioloog in de operatiekamer}

Waarom zou een anesthesioloog überhaupt dilemma's tegenkomen in de perioperatieve zorg? Als dienstverlenend vak zou het meeste voor ons georganiseerd moeten zijn. Maar ons vak heeft zich geëvolueerd, we doen ook aan pijnbestrijding, sommigen van ons werken op de intensieve zorg afdeling, anderen op de spoedeisende hulp afdeling. De polikliniek, waar alle patiënten vooraf aan een operatie gezien worden vraagt aandacht, maar ook de postoperatieve pijnbestrijding. In de perioperatieve zorg, dat is de zorg rond de operaties, is de coördinerende taak steeds meer op de voorgrond gekomen. Als men zou willen charseren, zou men zelfs kunnen zeggen dat een anesthesist scherprechter is over de volgorde waarin patiënten geopereerd worden. De normale volgorde is acuut, minder acuut, daarna electief. Niet moeilijk zult u zeggen. Toch zijn er nu al vele dilemma's. Vele belangen botsen. Wat nu te doen met twee gevallen van verschillende vakgroepen, die voor beide vakgroepen even urgent zijn? Een criterium zou kunnen zijn, dat de meest levensbedreigende aandoening voorgaat. Maar dit weten we vaak pas als we bij beide patiënten niets zouden doen. Moet de meest machtige chirurg voorgaan of die met de grootste mond (figuurlijk dan)? Het is en blijft een moeilijke beslissing.

$\mathrm{Nu}$ maken we het iets complexer. We hebben natuurlijk ook nog te maken met het management. Om dit te verduidelijken geef ik een waar gebeurd voorbeeld uit mijn eigen nachtdienst. Zoals $u$ weet moeten de Nederlandse ziekenhuizen afgerekend gaan worden op prestatie indicatoren. Een van die indicatoren is de indicator hoe snel een heup geopereerd wordt. De indicator zegt dat de patiënt met de gebroken heup binnen 24 uur na de dag dat hij/zij binnenkomt geopereerd moet worden, anders lever je slechte kwaliteit van zorg. Dit is een duidelijke regel. ${ }^{1}$

De patiënt met de gebroken heup is 87 jaar en in slechte algemene lichamelijke en psychische toestand. Volgens de familie is ze al langere tijd dement en bij preoperatieve visite is er moeilijk met haar te spreken. Tegelijkertijd staat er een patiënt van 26 jaar op de lijst, die via transplantatie een donornier moet krijgen van de chirurgen. $U$ moet weten dat een nier na het uitnemen binnen 24 uur getransplanteerd moet worden, om een goede kans op succes te hebben. 
Beide patiënten wachten al 20 uur op hun operatie omdat eerst het dagprogramma afgewerkt moest worden en de operatie kamer beperkt is in zijn capaciteit. Wie gaat nu voor? De patiënt van 87 jaar, m.a.w. de indicator en de goede naam van het ziekenhuis op korte termijn, of de patiënt van 26 jaar, die na niertransplantatie lang een redelijk gezond en kwalitatief hoogwaardig leven kan leiden? Ik ga u niet de uitslag van dit dilemma verklappen, wel kan het beide kanten opgaan.

Hier ziet men de directe confrontatie tussen betrokken dokters op de werkvloer en het ziekenhuis-management, dat een systeem financieel haalbaar moet maken, en de reikwijdte van besluiten misschien soms niet overziet.

De krappe financiering van de ziekenhuizen in het algemeen vraagt, zelfs op academisch niveau, wat het meeste geld opbrengt. Of anders gezegd: waar maken we de meeste winst op? U kunt nu denken, daar houden ze zich toch niet mee bezig in een academisch ziekenhuis. Ik kan $u$ verzekeren dat dit op het ogenblik een dagelijkse vraag is waar artsen mee geconfronteerd worden. In een academisch ziekenhuis is de winst niet voor de individuele dokter of zijn inkomen, maar is de winst voor het ziekenhuis en daardoor voor het overleven van het ziekenhuis. Indirect is dit dan wel weer voor de individuele dokter opdat deze verder kan werken.

Nu maakte de voormalige Minister Klink het nog moeilijker. Hij introduceerde het begrip marktwerking in de zorg. Waarom zou dit goed zijn? In een advies van de Raad Van Volksgezondheid uit $2003^{2}$ worden drie redenen gegeven.

1. Het gevoerde beleid van aanbodregulering is de belangrijkste oorzaak van wachtlijstproblematiek. M.a.w.: er is een beperkt aantal artsen, dat de patiënten kan helpen.

2. De organisatie van de zorg moet kleinschaliger en gevarieerder worden en beter aansluiten op de wensen van de bevolking. M.a.w.: diversiteit in de zorg, maar dit is duur.

3. Het verzekeringskarakter van de ziekenfondsverzekering moet hersteld worden. Daarbij merk ik op dat je niet alles kunt bekostigen en er keuzes gemaakt moeten worden. 


\section{Bij punt 1:}

De sleutel tot het in gang zetten van marktwerking is een selectieve invoering van Diagnose Behandelcombinaties (DBC's). Vroeger werd een arts per verrichting betaald. Bij een DBC vindt betaling plaats op basis van een (waarschijnlijkheids)diagnose. Gedachte hierachter was om het aantal onnodige verrichtingen terug te dringen en de zorg betaalbaar te krijgen. Bij marktwerking zullen zorgverzekeraars voor een zo laag mogelijke prijs inkopen. Maar verzekeraars kunnen dit pas doen als ze over keuzemogelijkheden beschikken. In het advies van de Raad voor de Volksgezondheid wordt dan ook gevraagd om meer capaciteit dus meer zorgverleners.

\section{Bij punt 2:}

Geld wordt verdiend met electieve operaties omdat ze planbaar zijn en via allerlei maatregelen de efficiëntie kunnen verbeteren (overigens ook niet onbeperkt). In het advies van de Raad voor de Volksgezondheid wordt gezegd dat er onderdelen van de medisch specialistische zorg zijn die niet geschikt zijn voor marktwerking of waar marktwerking tot aantasting van de publieke belangen kan leiden. Men doelt hier op patiënten waar een ziekenhuis "verlies" op lijdt. Dit zijn bijvoorbeeld patiënten binnen de acute zorgverlening want die is niet planbaar, of de patiënt met een ingewikkelde aandoening die multidisciplinaire, topklinische zorg nodig heeft. Voor dergelijke patiënten willen we een specifieke aanvullende bekostiging en hebben we een contracteerplicht van verzekeraars nodig om deze zorg te kunnen blijven bieden.

\section{Hiermee komen we bij punt 3:}

Als samenleving maken wij de keuze of wij dit zo willen. Op ziekenhuisniveau zien we, net als op de ok, dat het financieel haalbare botst met persoonlijke belangen. Als je zelf of jouw vader, moeder, of kind acuut ziek wordt kan het even duren voordat je geopereerd wordt. Dit kan de dood tot gevolg hebben. Voor iedereen is dit bijna niet te accepteren. Heden ten dage wil een samenleving alles: een goedkope zorg, de beste zorg, dicht in de buurt. Als dit in het individuele geval niet lukt, is de wereld te klein.

De afwegingen hoe, wat, wanneer te plannen zijn zo complex dat er hele computersystemen voor nodig zijn om dit te doen. De menselijke kant is voor deze "artificial intelligence" vaak moeilijk te bevatten. Ik 
pleit ervoor om de "human factor" niet te vergeten en met elkaar na te blijven denken welke keuzes we maken. Bijv. zoals de raad voorstelde door de academische zorg buiten de DBC systematiek te houden. Om met elkaar na te denken wat academische zorg is. Welke patiënt we nog wel opereren en wie niet. De mensen in onze maatschappij zijn het klankbord van de beleidsmakers in de medische zorg. Zij moeten via de politiek duidelijk maken, waar zij voor zouden kiezen ${ }^{2,3,4}$

De werking in de zorg anno nu doet me denken aan een parallel in de economie, waar uiteindelijk persoonlijke belangen, zoals de vervulling van ambities, de dialoog tussen mensen monddood maakte.

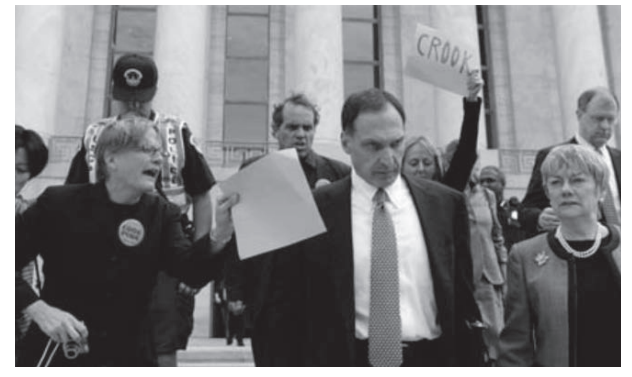

Woedende demonstranten omringen Richard Fuld van de failliete bank Lehman Brothers in oktober 2008. Foto Reuters

Zoals de foto laat zien hebben we de laatste jaren wat problemen in de economie gehad. We moeten leren van wat Richard Fuld meegemaakt heeft. De kredietcrisis kwam door het dereguleren, privatiseren en saneren van instanties, die invloed hebben op de economie, zoals banken. Dit lijken op zich doordachte manieren te zijn om een complex systeem te kunnen regisseren. Maar in een stuk in de NRC van 6 juli 2009, "risicoloos bankieren bestaat niet", wordt de realiteit geschetst van financiële innovaties en personen met een bètavooropleiding, die ik beschouw als logische denkers, die werden weggehaald bij het risicomanagement. 5 Juist zij werden aan de kant van de productontwikkeling gezet om de tomeloze jacht naar winst te stillen. Zeer ingewikkelde producten werden ontworpen en verkocht, het financiële risico steeg terwijl hard kapitaal als onderpand als sneeuw voor de zon verdween. ${ }^{5}$

Parallel in de zorg zie ik de vraag om hulp alleen maar toenemen. Ingewikkelde computersystemen worden gemaakt om ingewikkelde producten aan de man te brengen (de DBC's). Maar voor uitbreiding van het zorgaanbod in de vorm van professionele hulpverleners is geen kapitaal beschikbaar. Ik hoop dat we de menselijke maat niet uit het oog verliezen en ons over 20 jaar als Richard Fuld voelen, verantwoordelijk voor de ondergang van een megaziekenhuis waar de individuele patiënt verloren is gegaan in bureaucratische organisatiestructuren. 


\section{Het tweede deel van het drieluik: de opleiding tot specialist}

Marktwerking moet niet alleen geïntroduceerd worden in de gezondheidszorg maar ook in de opleiding tot specialist. Een gemiddelde opleiding tot medisch specialist kost $€ 850.000$ aan de overheid. Per jaar wordt $€ 1.000 .000 .000$ geïnvesteerd in de medische vervolgopleiding. $U$ begrijpt dat het zeker in deze tijd korter en goedkoper moet, natuurlijk met behoud van kwaliteit.

Wat is nu een van onze grootste dilemma's, mijn inziens, in de opleiding. Vroeger was het duidelijk. Je was er voor je opleiding 7 maal 24 uur, 5 jaar lang lang. Natuurlijk had je recht op een beetje slaap: laten we zeggen 5 uur per nacht. Je werkte minimaal 12 uur per dag. Daarna studeerde je 2 uur in je eigen tijd. En je deed diensten: eens in de drie dagen. Een vrij weekend per maand. En 20 dagen vakantie per jaar.

Totaal deed je meer dan 15.000 uur anesthesie. Je deed dus heel veel praktijk en als je ergens niet zo goed in was, dan zei je opleider dat je maar wat langer moest bijscholen op dat gebied. Dit had natuurlijk veel nadelen. Misschien was het niet heel veilig voor de patiënt. Op een gegeven moment leerde je niet veel meer, want je was moe. En de theoretische opleiding kwam in het gedrang. ${ }^{6}$

Hoe ziet dit er tegenwoordig uit. Je doet 5 jaar opleiding waarvan 1 tot 1.5 jaar intensive care, 3 maanden pijnbestrijding, 3 maanden polikliniek en 3 maanden op pad voor bijscholing. En je hebt ongeveer 6 maanden vakantie. In het ongunstigste geval doe je 2 jaar en 3 maanden anesthesie aan 46 uur per week, waarvan 3 uur per week eraf gaan voor interne theoretische bijscholing. Je komt uit op ca. 5000 uur anesthesie. Je kunt er een heleboel andere berekeningen op los laten maar zelfs als je alles onder praktische anesthesie telt: en dat is 4.5 jaar maal 9.5 uur kom je op ca. 10.000 uur. Daarbij is de opleider niet meer flexibel en kan niet bijsturen.

Anesthesie is een ervarings- en praktisch vak bij uitstek. Veel doen is zeer belangrijk. Hoe je het ook bekijkt, de tijd voor de praktische opleiding is veel minder: 10.000 uur nu t.o.v. 15.000 uur vroeger. Dus wat zijn de oplossingen? Hiertoe zal ik twee modellen die door Medisch Contact gepubliceerd zijn met u bespreken. 


\section{Het eerste model, voorgesteld door de NFU}

Op 22 april 2010 kwam de NFU met de oplossing voor dit toekomstige ervaringsprobleem. ${ }^{7}$ In het medisch contact schrijft men "Specialistische opleiding kan korter". ${ }^{8}$ Ze constateren de problemen waar wij dagelijks mee bezig zijn.

"Het aanbod van artsen en hun inzetbaarheid is aan het verschuiven. De traditie van artsen die dag en nacht in touw zijn voor hun patiënten, heeft plaatsgemaakt voor een meer genuanceerde praktijk. De artsenij is al lang niet meer een fulltime way of life, waar al het overige ondergeschikt aan is of voor moet wijken. Tegelijkertijd treedt een feminisering van het artsenberoep op".

Wat dit laatste met het probleem te maken heeft, weet ik trouwens niet. Men gaat verder, naar wat waarschijnlijk het ware probleem is.

"En ten slotte hebben ziekenhuizen een kwaliteitsprobleem als het gaat om de meer routinematige specialistische basiszorg. In de huidige praktijk wordt hiervoor vaak een beroep gedaan op anios, basisartsen niet in opleiding. Na de studie geneeskunde gaan zij vaak zonder aanvullende opleiding in deze basiszorg aan de slag. Met als gevolg dat zij zeker in de eerste jaren vaak een beroep doen op medische specialisten. Deze moeten alsnog (de verantwoordelijkheid voor) de zorg overnemen of worden geconsulteerd. De potentiële meerwaarde van anios voor deze basiszorg blijft daardoor onbenut. Feitelijk zijn zij onvoldoende gekwalificeerd voor het werk dat ze doen"

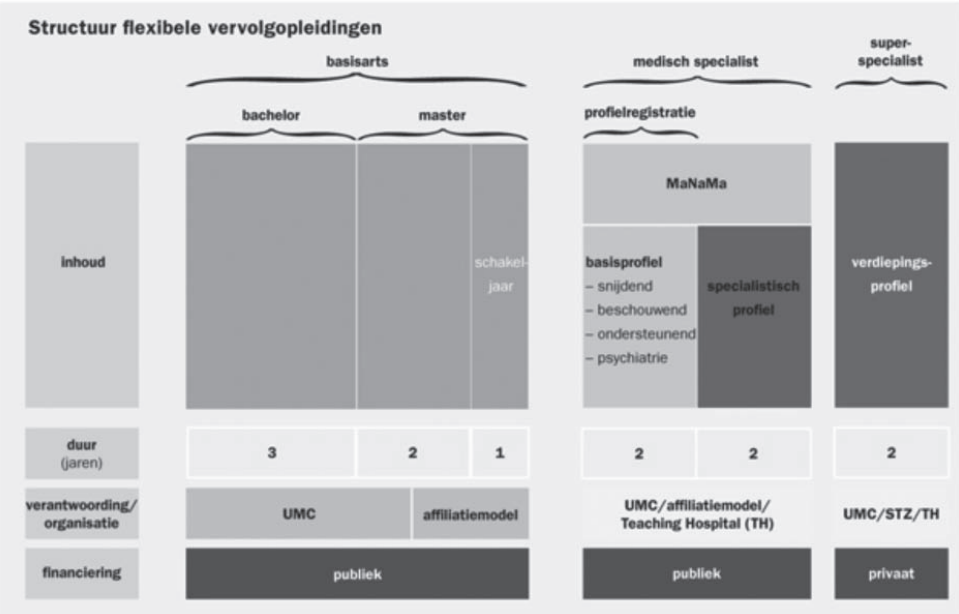


In het voorstel van de NFU krijgen alle basisartsen een kwalitatief goede vervolgopleiding. Dus de anios die nu zonder vervolgopleiding functioneren, verdwijnen van het toneel.Dekwaliteitvan de routinematige basiszorg in de ziekenhuizen gaat op die manier fors omhoog en de patiëntveiligheid neemt toe. In navolging van ontwikkelingen in België introduceert de NFU hiervoor het model Master Na Master - kortweg MaNaMa. Het basis-, specialistisch en verdiepingsprofiel sluiten aan bij de diverse fasen van de beroepsontwikkeling en de manier waarop de combinatie leren en werken tijdens de vervolgopleiding wordt ingevuld (zie figuur). Een MaNaMa-programma telt ongeveer 50 onderwijsdagen op jaarbasis voor verdieping in disciplineoverstijgende competenties zoals samenwerken, patiëntveiligheid, communiceren en organiseren. $\mathrm{Na}$ afronding ervan heeft de basisarts de keuze om - eventueel tijdelijk - te stoppen of om het specialistische profiel te volgen. Ook dit is onderverdeeld in een vakinhoudelijk en disciplineoverstijgend deel. Basis- en specialistisch profiel samen vormen de tweede master en de opleiding tot medisch specialist. Wie na het basisprofiel stopt, kan aan de slag in de specialistische basiszorg. De lengte van opleidingsfasen kan per discipline enigszins variëren, mede afhankelijk van de Europese normen.

Bij sommige specialismen is hierna een fase van superspecialisatie nodig om adequaat op het niveau van een medisch specialist te kunnen functioneren. Dat geldt bijvoorbeeld voor thoraxchirurgie en neurochirurgie. Als ik dit vrij zou vertalen naar de anesthesie, zouden alleen de intensive care en de chronische pijn voor superspecialistische verdieping in aanmerking komen. De basis-specialistische zorg voor anesthesie zou in het ze en 4e leerjaar geleerd worden. Waarbij nog wel 50 werkdagen aan overstijgend onderwijs geleverd moeten worden. $\mathrm{Na}$ aftrek van vakanties en anesthesieonderwijs kom ik op 3404 uur anesthesie in de praktijk binnen dit model, voorgesteld door de NFU. Dit is 1500 uur minder, dan binnen het huidige curriculum. Met het complexe scala van ingrepen vraag ik me toch af wie deze voorstellen doorrekent. En of de consequenties van het voorstel wel goed doordacht zijn. $^{8}$ 
Een tweede model dat mijn voorkeur heeft wordt voorgesteld door Prof. Knape uit Utrecht. Hij en zijn medeauteurs schrijven in Medisch Contact:

"Ruim een decennium na het spraakmakende artikel, "Te oud, te knap en te duur", waarin de hoogleraren Blijham en Bleker pleitten voor een kortere opleiding tot medisch specialist, heeft hun betoog weinig aan actualiteit ingeboet." 9

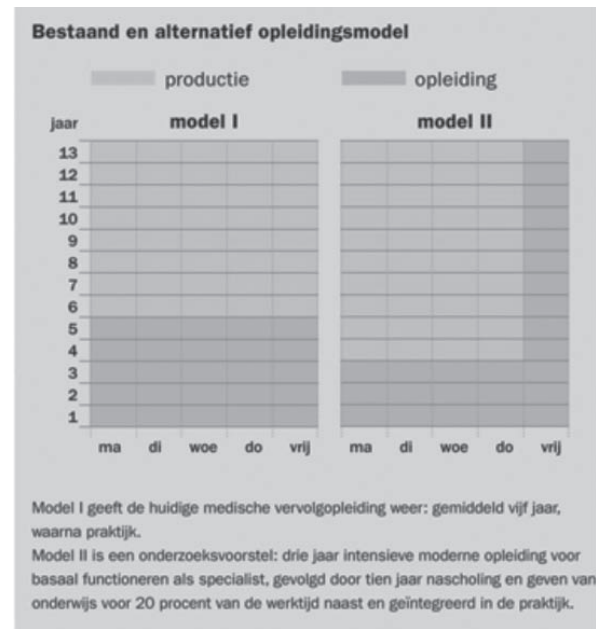

In het model van Knape et al. gaat de jonge klare, na zijn 3-jarige vervolgopleiding, aan de slag voor vier dagen in de week op basisspecialisten niveau, en besteedt tien jaar lang één dag in de week intensief aan nascholing en het geven van onderwijs. In de loop van de jaren breidt de specialist zijn bekwaamheden uit op basis waarvan hij/zij deelcertificaten verwerft. De opleiding wordt aantrekkelijker en motiveert: het onderscheid tussen de rol als leraar (teaching) en producent van zorg (health care) wordt helder. Specialisten kunnen eerder in het praktijkproces worden ingezet. Door onderwijs te geven aan aios en anderen leert de specialist zelf ook - onderwijs en leren krijgen steeds meer een intercollegiaal karakter.

Als we dit voorstel doorrekenen kan er veel meer tijd aan praktijk gerichte anesthesie besteedt worden, bijvoorbeeld de eerste drie jaar als een soort MaNaMa: toch ca. 5000 uur. Daarna doe je gewoon anesthesie verder en krijg je een vervolgopleiding van 44 dagen per jaar voor 7 jaar. Dit is ca. 3000 uur. Maar verder ben je dag in dag uit met het vak 
anesthesie bezig. Een gedegen opleiding dus van 10 jaar met veel meer dan 15.000 uren praktijkervaring. ${ }^{9}$

Het nadeel zal wel zijn dat hiervoor organisatievermogen nodig is, het relatief duur is en ik mij niet kan voorstellen dat de salarissen gelijk kunnen blijven. De NFU, de overheid, en de AIOS zullen minder blij zijn met model 2.

$U$ ziet weer in de opleiding terugkeren dat er frictie bestaat tussen complexiteit en functionaliteit van de organisatiestructuur enerzijds en bereiken van inhoudelijke kwaliteit anderzijds. Afhankelijk door wiens bril gekeken wordt, komt men met zijn of haar oplossing.

Mijn mening op basis van de twee voorgestelde modellen is, dat we moeten komen tot verschillende niveaus van opleiding. Afhankelijk van het gewenste niveau moet een minimaal aantal uren praktijkervaring zijn opgedaan naast het volgen van simulatieonderwijs ${ }^{10}$ en het afleggen van toetsen betreffende de theoretische kennis. De mijlpalen die bereikt worden tijdens de opleiding, dienen vastgelegd te worden door nationaal en internationaal erkende certificaten. Dit maakt uitwisseling van personen met bepaalde expertise tussen centra van nationaal en internationaal niveau eenvoudiger en vergroot de mobiliteit van talenten. Door gelijkschakeling van het examensysteem ontstaat een grote vijver aan mensen met bepaalde kwaliteiten, waar het individuele centrum in de toekomst makkelijker die persoon gaat vinden met de kwaliteiten, die lokaal optimaal benut kunnen worden.

Zijn er parallellen in de rest van de maatschappij? Zoekt het medische beroep als enige naar nieuwe manieren van opleiden? Nee, natuurlijk niet.

Ik zou me willen spiegelen aan eenzelfde organisatiestructuur als die der medische professie, nl. de rechterlijke macht. Deze is de laatste jaren onder een enorme maatschappelijke druk komen te staan. Aan de ene kant is er een tekort aan rechters, waardoor men mensen met een verkorte opleiding laat instromen. Aan de andere kant is er een roep naar meer opleiding en nascholing. Het Internet staat bol van de gepeperde uitspraken. Raadsheer Wedzinga"1 schrijft op zijn website:

"Ik heb de uitspraken in de periode 12 februari 2009 tot en met 19 februari 2009 bestudeerd en kwam tot de conclusie dat het aantal rechterlijke dwalingen niet op de vingers van twee handen te tellen zijn" 
Even later spit hij twee casussen verder uit en zegt hij:

"Het zijn twee recente rechterlijke uitspraken, waarin de rechters er een potje van hebben gemaakt...... In de tweede zaak zaten rechters die niet alleen een permanente opleiding meer dan nodig hebben, maar die de komende jaren verplicht in de schoolbankjes zouden moeten zitten"."1

Voor een buitenstaander, zoals ik, lijkt het ook hier te wringen tussen hoeveelheid opleiding, praktijkervaring (of het gebrek er aan), en de werkdruk. Net als in de medische wereld lijkt de dialoog tussen de mensen op de werkvloer, de beleidsmakers en de samenleving een ondergeschoven kindje te zijn. Een eenvoudigere organisatiestructuur zou veel helpen, met minder mensen die hun stempel op de geschiedenis willen drukken. Vergelijkbare problemen zien we ook in de onderzoeksomgeving terugkomen.

\section{Het derde deel van het drieluik: Onderzoek}

U zult zich natuurlijk niet verwonderen dat het grootste deel van het onderzoek dat ik doe zich afspeelt in de perioperatieve setting. Daarom wil ik me hier toespitsen op ons perioperatief pijnonderzoek en de organisatie ervan. Bij dit derde onderdeel van mijn rede wil ik eerst naar de parallel gaan.

Op deze vakantie werd ik gegrepen door een boek uit de bibliotheek van het schip "Polio: an American story". ${ }^{22}$ Mijn zoons zeiden dat ik volkomen gek was om een geschiedenisboek in mijn vrije tijd te lezen. (Dit zeiden ze trouwens in andere bewoordingen). Maar u moet weten dat ik, toen ik een studie moest kiezen, tussen drie richtingen gekozen heb, te weten: geneeskunde, geschiedenis en economie. Dus dit boek was hobby.

De race om een therapie te vinden voor polio leest als een thriller. Hoewel in 1911 Flexner in de New York Times zei dat een therapie voor polio bijna gevonden was, duurde het nog 40 jaar voordat dit daadwerkelijk zo was. Een van de redenen was dat het onderzoek op eilandjes bleef gebeuren, vooral in de USA. Vooruitgang werd er pas geboekt toen er een nationale coördinatie kwam, opgericht door de National Foundation for polio research, een privé initiatief. 
Deze stichting formuleerde drie vragen die opgelost moesten worden:

1. Hoeveel types polio zijn er?

2. Hoe komen we aan genoeg aanbod van virussen van de verschillende typen voor een vaccin?

3. Wat is de epidemiologie en pathogenese van polio?

Hiervoor kwamen subsidies vrij om op langere termijn onderzoek te doen en werden onderzoeksinstituten geschapen waar dit kon gebeuren. Gesubsidieerd werden o.a. Jonas Salk en Albert Sabin. Hierdoor ontstond in 1954 het geïnactiveerde Salk vaccin, dat getest werd in een deels gerandomiseerde en deels gecontroleerde trial, de grootste tot dan toe over 1.3 miljoen mensen. De analyse van deze trial duurde een jaar en was gunstig voor het vaccin. Het verzwakte maar levende Sabin vaccin werd vervolgens op 3 miljoen mensen getest in de USSR en had ook daar een gunstig resultaat.

De lessen die wij hiervan kunnen leren zijn dat formulering van de onderzoeksvraag vooraf en samenwerking bij onderzoek grotere kans van slagen geeft op het behalen van een gesteld doel. Focus van mankracht en middelen zijn onontbeerlijke factoren bij dit proces.

Een derde les, die we uit dit boek kunnen leren is dat de traditionele geneeskunde niet altijd in staat is een goede therapie te leveren. Uit onverwachte hoek, zoals de alternatieve geneeskunde, komen behandelingen naar voren, waarop de patiënt beter lijkt te reageren. Tot 1938 werden alle kinderen met polio geïmmobiliseerd. Een "selfmade nurse", Kenny Roberts, kwam met een nieuwe therapie: "hot Packs" en oefening. De resultaten op lange termijn bij de kinderen die hiermee behandeld waren, waren veel beter. $\mathrm{Na}$ veel scepsis en weerstand van de zijde van het conservatieve, medische establishment, werd deze behandeling als standaard geaccepteerd..$^{12}$

Hoe zouden we de drie lessen,

1. Coördinatie

2. Grootscheepse trials

3. Traditionele geneeskunde versus alternatieve therapie nu op ons eigen onderzoek kunnen toepassen? 


\section{Beginnende bij punt 3:}

Het fenomeen pijn is complex, waarbij een onnoemlijk aantal uitwendige en inwendige factoren van belang is. Daarom is pijn zeer moeilijk te beïnvloeden. Dat zien we ook als we naar de cijfers kijken hoeveel patiënten pijn lijden na operaties. Eigen en internationale studies tonen aan dat een op de drie patiënten in de postoperatieve periode een Visual Analogue Scale (VAS) van meer dan 7 op een schaal van 10 hebben. Dat wil zeggen dat teveel patiënten pijn lijden na een operatie. Om dit te verbeteren hebben veel ziekenhuizen een acute pijn service opgericht en nationale richtlijnen geïmplementeerd. Maar dit heeft er niet toe geleid om de standaard te halen, die door veel nationale en internationale experts en inspecties is vastgesteld: dat maar $5 \%$ van de patiënten na een operatie ernstige pijn (VAS> 7 ) mogen hebben ( $5 \%$ of patients should experience severe pain by the year 2002, Audit Commission Anaesthesia under Examination, Audit Commission, London 1997). Dit is in Nederland een belangrijk onderwerp, blijkend uit de Nederlandse Technische Afspraak (NTA) van het ministerie, die de basiseisen beschrijft voor een veiligheidsmanagementsysteem (VMS). Een van de indicatoren voor dit systeem is de indicator: "voorkomen van onnodig lijden van patiënten door pijn". Maar ondanks de enorme hoeveelheid tijd en geld, die we in onderzoek en organisatie steken, komen we niet erg snel vooruit op dit gebied.

Toch blijven wij over de hele wereld veel tijd en geld aan onderzoek om pijn te bestrijden besteden. Wij hopen namelijk aangrijpingspunten in de pijnbaan te vinden, waarop we de vicieuze cirkel van de chronische pijn kunnen doorbreken. Wij, dat zijn Jaap Patijn, Maarten Van Kleef, Ronald Deumens en ondergetekende, o.l.v. Bert Joosten, maar ook in de kliniek met bijv. Madelon Peters en alle promovendi en andere stafleden en assistenten, zijn o.a. op zoek naar mechanismen, die in het eigen lichaam zorgen voor de onderdrukking van pijn. Als we deze mechanismen kunnen beïnvloeden, kunnen conditioneren, kunnen we misschien vooruitgang boeken.

In toenemende mate wordt ook in dierexperimenteel onderzoek aangetoond dat dergelijke mechanismen bestaan. Dit wil ik illustreren aan de hand van 1 van onze onderzoekslijnen betreffende het concept "Healing Environment" of "genezende omgeving". Veel ziekenhuizen worden al gebouwd volgens dit concept. Licht, luchtig, lekker ruiken, een prettige omgeving. Er wordt gezocht naar mogelijkheden om de omgeving te verbeteren, waardoor de patiënt minder acute pijn 
ervaart. Spectaculaire dierexperimentele resultaten hebben we geboekt door ratten in het laboratorium in grote (zogenaamde enriched environment of verrijkte behuizing) en kleine behuizing te laten leven. Ratten in de grote behuizing hadden minder last van pijnprikkels. Deze pijnvermindering heeft een biologisch substraat in de vorm van verminderde activering van microglia cellen. Hoe het mechanisme van deze verminderde activering precies functioneert, is nog onbekend en onderwerp van verder onderzoek.

Maar ook een eigenschap van mensen zelf, zoals optimisme, kunnen aangrijpingspunten zijn om pijn te verminderen. In de dies natalis toespraak van Madelon Peters vertelde ze ons dat "Happy people live longer". ${ }^{3}$ Of optimisme ook een factor is, die van invloed is op het ontwikkelen van chronische pijn na operatie, weten we eigenlijk niet maar zouden we ons goed kunnen voorstellen. Wat zou mooier zijn dan dat we patiënten voorafgaande aan een operatie gedragstherapie geven, zodat ze na de operatie minder pijn hebben?

Alternatieve mogelijkheden om pijn te benaderen die niet volgens de traditionele Westerse geneeskunde zijn, worden overigens al in de praktijk toegepast. Ook heb ik deze zomer een voordracht bijgewoond over acupunctuur als therapie bij pijn. De respons in de zaal was overweldigend. Mensen geloven erin. Dichterbij huis: mijn zuster, Marilou Verhoef-Marcus, werkt op de afdeling oncologie in Leuven met patiënten die therapieresistente pijn hebben. Zij past aromatherapie, reiki en massages toe. Als curatief ingestelde dokters moeten we veel meer gebruik maken van dit soort therapieën: baat doen ze, kwaad kunnen ze niet, en patiënten voelen zich beter.

Natuurlijk doen we ook onderzoek binnen de gangbare natuurwetenschappelijke geneeskunde. Niet alleen wordt onderzoek naar de preventie van pijn verricht, maar ook naar herstel van fysiologische, dus normale signaaltransductie. Bij een operatie, maar ook na trauma, gaan er zenuwen kapot. Dit zorgt niet alleen voor functieverlies, maar ook voor het ontstaan van pijn. Als we deze zenuwen weer netjes aan elkaar laten groeien, zou er herstel van functie moeten zijn maar misschien ook vermindering van pijn. Met de vakgroep van Cor Koning worden er nieuwe materialen ontwikkeld om deze groei te faciliteren. Uiteindelijk bekijken wij wat het nieuwe materiaal doet om de pijn te verminderen, maar we kijken natuurlijk ook naar het functieherstel. 
Wat ik tot nu toe aan onderzoekslijnen besprak is maar een deel van wat we doen en lijkt zeer divers. ${ }^{14,15}$ Hoe komt dit? De aard van de beestjes die onderzoek doen, is natuurlijk een oorzaak. Wij zijn nu eenmaal nieuwsgierig!!!!! Een patiënt komt met een vraag, die zeer interessant is, en een translationele onderzoekslijn kan geboren zijn. Maar er zijn ook andere factoren die een rol spelen bij deze diversiteit. Waar is geld voor onderzoek te krijgen? Alleen al een dergelijk lab te laten draaien kost ongeveer $€ 120.000$ per maand, en het wordt vooral extern gefinancierd. Meer dan $€ 1.500 .000$ per jaar moet aan grants worden binnen gehaald. Dus bij een onderzoeksvraag hoort ook een bron van financiering. Vaak zijn die bronnen moeilijk te vinden. In het zevende kaderprogramma van de EEG komt pijn maar één keer voor. En nu kom ik weer terug op een dilemma: we willen focus maar er moet ook brood op de plank komen. In de praktijk blijken beide doelen realiseerbaar te zijn omdat aan het einde van de rit de diverse onderzoekslijnen in het grote geheel van pijnonderzoek blijken te passen.

Hiermee komen we op punt 1 en 2 van de parallel met het polio onderzoek: coördinatie en grootscheepse trials. Elke hypothese binnen het pijnonderzoek moet uiteindelijk, gerandomiseerd, multicentrisch, in zo groot mogelijke populaties, getoetst worden.

Dit is alleen mogelijk door coördinatie op nationaal en internationaal niveau. Wereldwijd zou er eigenlijk een coördinerend orgaan moeten worden opgericht dat geld en focus zou moeten verdelen. Per jaar worden miljarden aan pijnresearch besteed. Een coördinerend orgaan voor pijnonderzoek zou dit wel makkelijker moeten maken, niet bureacratischer. Voorkeur heeft dus een beperkte groep van experts die korte lijnen hebben. Er zou een wereldwijde Medisch Ethische Toetsingscommissie voor pijn moeten komen. De METC van het MUMC doet geweldig werk, maar weet inhoudelijk over een uiteenlopend scala van onderwerpen in de medische wetenschap iets tot een bepaald niveau. Een internationale commissie zou inhoudelijk in de breedte en diepte alles van pijnonderzoek af moeten weten. Deze commissie kan zeer grote trials coördineren (conform het polio onderzoek). In die commissie zitten mensen die hun sporen verdiend hebben in onderzoek over pijn en die het algemene belang stellen boven hun eigen ambities. U ziet al, waarschijnlijk een Utopie. 
Is dit nieuw? Nee natuurlijk. In het blad Anesthesiology in 2010, wordt een poging beschreven door de "Food and drug administration" (FDA) in Amerika om een publiekprivaat rechterlijk orgaan samen te stellen om een geneesmiddel tegen chronische pijn te ontwikkelen. ${ }^{16}$ Als dit soort samenwerkingsverbanden succesvol blijkt te zijn, zouden we dit kunnen verbreden naar Europa, en uiteindelijk naar de hele wereld.

\section{Hiermee kom ik tot mijn conclusie}

Bij het doorvoeren van veranderingen moeten eerst werkbare kaders worden opgesteld, na dialoog met professionals op de werkvloer, binnen de zorg met de samenleving als klankbord. Deze professionals moeten mensen zijn die vakinhoudelijk midden in de materie zitten en geen mensen, die om wat voor reden dan ook, makkelijk vrijgemaakt kunnen worden. In samenwerking met deze professionals moeten managers deze kaders proberen te vertalen naar een werkbare realiteit die financieel haalbaar is. De argwaan die over en weer lijkt te heersen tussen beleidsmakers en professionals zou weggenomen moeten worden. Dit zou in theorie niet moeilijk moeten zijn, aangezien het merendeel van de mensen streeft naar hetzelfde: goede zorg en goed onderwijs geven, goed onderzoek doen. Het huidige denken lijkt een korte termijn denken, waar persoonlijke motieven een te grote rol spelen. Het algemene belang op lange termijn zou zwaarder moeten wegen. 


\section{Dankwoord}

In afsluiting wilde ik iedereen danken die hier is. Zonder de hulp van vele mensen bereik je niets. Het dankwoord is altijd zeer moeilijk en bij voorbaat weet je al dat je mensen voor het hoofd stoot, maar toch een poging. Ten eerste wilde ik de RvB, Pof. Steinbusch, maar vooral de decaan danken voor het in mij gestelde vertrouwen. Vele leermeesters die voor mijn vorming zeer belangrijk waren ben ik tegen gekomen. De belangrijkste waren Prof Jan Baan, Prof. Ted Stanley en Prof. H. van Aken.

Prof. Johnny Job: ondanks dat $u$ me te jong vond om mij als studentenassistent te laten beginnen op het klinisch fysiologisch laboratorium in Leiden heb ik er 4 jaar kunnen werken en hebt $u$ de basis gelegd voor mijn interesse in de wetenschap.

Prof Ted Stanley: De enorme creativiteit, energie en enthousiasme voor nieuwe ontwikkelingen, maar ook uw menselijkheid zal altijd een voorbeeld voor mij zijn.

Prof. Hugo van Aken: Meer dan 10 jaren van mijn leven heb ik met $u$ samen mogen werken. In deze tijd is er een enorme productiviteit geweest. Prijzen, opleiding etc werden binnen gehaald. Uw energie en doorzettingsvermogen hebben vele deuren geopend. Zeer trots ben ik op het feit dat ik sinds 2004 als Ausserplanmaessige-professor benoemd ben aan de Westfaelische Wilhelms Universitaet, Muenster.

De tijd in Leiden, Leuven, en Muenster hebben vele vriendschappen opgeleverd waaronder om er een paar te noemen die met Gogarten, Struemper, Brodner, Mollhoff, Loick, Buerkle, Wouters, Van de Velde, Vertommen, Soetens, en Jan van Zundert. Daarna ben ik in 2001 naar Maastricht gekomen. Ik denk dat we daar nuéén van de meest productieve academische afdelingen anesthesie hebben opgebouwd. Doordat iedereen zich enorm inzet in de kliniek kon de afdeling natuurlijk zover komen. Toch wil ik een aantal mensen met naam noemen. Bert Joosten, is hoofd van het basale lab, een voorbeeld voor elke wetenschapper, en ook nog zeer aardig. Ronald Deumens is enorm creatief en heeft een tomeloze energie. Alle ondersteuners van onderzoek, met name voor mij natuurlijk Maurice Theunissen en Audrey Fiddelers, die met hart voor de zaak, de zaak draaiende houden. De vele promovendi, zoals o.a. Marcus Lancé, Esther Bouman en Boris Cox, die hele eigen lijnen opzetten. Ik wil natuurlijk ook alle andere promovendi bedanken voor hun inzet. De samenwerkingen met andere afdelingen zoals met de groep van 
Johan Heemskerk, Hugo ten Cate en Yvonne Henskens. De enorme goede samenwerking en productiviteit die we hebben met Madelon Peters. Cees de Jong van de chirurgie, waar we nauw mee samenwerken. Ook op de obstetrie, o.l.v. Jan Nijhuis, zijn we aan een krachtige uitbouw van onderzoek bezig met onderzoekers zoals Annemarie Vermelis, Martine Wassen, en Nicole Engel, die daar de organisatie op de verloskamer van mij overneemt. Ook onze samenwerking met de groep rond Dirk van Asseldonk (Dolphys), en de groep rond Cor Koning van de TU/e, is ons zeer waardevol.

Binnen de opleiding wil ik allereerst de assistenten bedanken, die hard werken en een aardige groep zijn, die constructief met mij proberen problemen op te lossen. Onze perifere opleiding onder leiding van André van Zundert, die van hoge kwaliteit is. En onze inofficiële vervolgopleiding in Genk o.l.v. René Heylen. Verder noem ik de steun die ik uit het concilium en de centrale opleidingscommissie krijg, vooral van Nicole Groenendal, Ronald Hortensius, en Patricia Liem, en van alle leden en bestuur. Een enorme hoeveelheid werk in de opleiding wordt verzet door Patrice Moonen, opleidingssecretaresse en Karin Houben, staflid, waarvoor dank.

Daarnaast wil ik alle secretaresses bedanken voor hun secretariële ondersteuning.

Ook de samenwerking met de Universiteit, afd. opleidingszaken, Albert Scherpbier, Marleen Gullikers, en Rene Stalmeier is zeer goed. Hans Gramke, die ondanks de zeer moeilijke tijd, die hij meemaakt, mij enorm steunt en Micha Sommer, die altijd een luisterend oor heeft. Ruud Timmer, Maarten van Kleef, die achter mij staan. Bij steun geven hoort af en toe een kritische noot, zodat je met beide voeten op de grond blijft staan. Die geven ze mij ook.

Mijn schoonfamilie en mijn familie wil ik danken. Voor mijn opvoeding en tegelijkertijd vriendschap mijn zus, mijn moeder en schoonmoeder. Mijn vader, die er helaas niet meer bij kan zijn, voor de keuze vrijheid tijdens mijn jeugd. Het eerste zetje in de studie geneeskunde gaf mijn zwager, voor mijn carriere is dit zeer belangrijk geweest. Mijn zoons met hun loyaliteit. En natuurlijk Nike voor haar steun en liefde.

Ik heb gezegd. 


\section{Referenties}

1. Indicatoren heup en pijn. www.kiesbeter.nl, www.zichtbarezorg.nl, www.igz.nl, wWw.anesthesiologie.nl

2. Marktwerking in de medisch specialistische zorg. Advies uitgebracht door de Raad voor de Volksgezondheid en zorg aan de minister van WVS, Zoetere 2003. Internet

3. H.A. Kreuzenkamp. Marktwerking in de zorg. Internet.

4. Dr. E.H. Hulst. Marktwerking blokkeert doelmatige zorg. NRC: 26 Juli 2010

5. Egbert Kaise. Bankiers hebben met onze welvaart gegokt. NRC:28 maart 2009

6. Kuhn CM. The innovative anesthesiology curriculum. Anesthesiology 2010;112:267-8

7. College medisch vervolgopleidingen en de NFU. De medisch specialist van straks. DiscussienotitieNFU. Internet 2010

8. Meininger AK, Velkeniers B, Heineman MJ, Borlefs J, Jaspers F. De medische specialist van straks. Medisch Contact 2010;65:792-31

9. Knape JTA, Ten Cate Th. J. Nog altijd te oud, te knap, te duur. Medisch Contact 2010;65,13:582-6

10. Byrick RJ, Naik VN, Wynands JE. Simulation based education in Canada: will anesthesia lead in the future? Can J Anaesth 2009;56:273-8

11. Wedzinga W. Zo maar een paar rechterlijke dwalingen. Internet 2009

12. David M. Oshinsky. Polio, an American Story. Oxford University Press. 2005. ISBN-13:978-0-19-515294-4

13. Peters M. Positive psychology and health: countering vulnerability with resilience. Speeches Dies Natalis 2010 MUMC

14. Evers AS, Miller RD. Can we get there if we do not know where we are going? Anesthesiology $2007 ; 106: 651-2$

15. Schwinn DA, Baiser JR. Anesthesiology physician scientist in Academic Medicine: A wake up call. Anesthesiology $2006 ; 104: 170-8$

16. Rappaport BA, Cerny I, Sanhai WR. Action on the prevention of chronic pain after surgery. Anesthesiology 2010;112:509-10 
